\title{
Performance of Broiler Chickens Offered Drinking Water Contained Water Extracted Beluntas (Pluchea indica L.) Leaf and Sugar Cane
}

\author{
A. Sudarman*, Sumiati, \& R. Kaniadewi \\ Department of Nutrition and Feed Technology, Faculty of Animal Science, Bogor Agricultural University \\ Jln. Agatis, Kampus IPB Darmaga, Bogor 16680, Indonesia \\ (Received 26-10-2011; accepted 29-06-2012)
}

\begin{abstract}
ABSTRAK
Hasil penelitian sebelumnya menunjukkan bahwa ekstrak daun beluntas dapat ditambahkan ke dalam air minum sampai taraf $\mathbf{1 0 \%}$. Guna mendapat manfaat ekstrak daun beluntas secara maksimal maka tujuan dari penelitian ini adalah untuk mempelajari pengaruh penambahan ekstrak daun beluntas pada taraf lebih dari $\mathbf{1 0} \%$ ke dalam air minum terhadap performa dan kolesterol daging broiler. Penambahan gula dilakukan pula untuk mengatasi rasa sepat akibat semakin tingginya taraf pemberian ekstrak daun beluntas agar tidak ditolak oleh ayam. Dua ratus enam belas DOC strain CP707 dipelihara selama 4 minggu dengan kepadatan 15 ekor $/ \mathrm{m}^{2}$. Anak-anak ayam tersebut diberi perlakuan air minum yang terdiri atas T0 (hanya air minum), T1 (air minum + anti stress komersial), T2 (air minum $+10 \%$ ekstrak daun beluntas), T3 (air minum $+20 \%$ ekstrak daun beluntas), T4 (air minum $+40 \%$ ekstrak daun beluntas), T5 (air minum $+80 \%$ ekstrak daun beluntas), T6 (air minum + $40 \%$ ekstrak daun beluntas $+1,6 \%$ gula), dan T7 (air minum $+80 \%$ ekstrak daun beluntas $+3,1 \%$ gula). Hasil memperlihatkan bahwa pemberian ekstrak beluntas lebih dari $10 \%$ menurunkan $(\mathrm{P}<0.05)$ bobot badan akhir, pertambahan bobot badan, dan memperburuk rasio konversi pakan. Dapat disimpulkan bahwa penambahan ekstrak daun beluntas kedalam air minum pada taraf yang lebih tinggi dari $10 \%$ tidak dapat memberikan hasil yang lebih baik meskipun telah ditambah gula, khususnya pada taraf $40 \%$ dan $80 \%$.
\end{abstract}

Kata kunci: ekstrak daun beluntas, sugar cane, air minum, antistress, performa broiler

\section{ABSTRACT}

Our previous study showed that the addition of water extracted beluntas leaf into drinking water could be used as an anti-stress and improved performance of broiler chicken. However, the addition was only up to $10 \%$ of drinking water. The objective of this experiment was to study whether the addition of sugar and water extracted beluntas leaf in levels higher than $10 \%$ of drinking water can give greater benefit on performances and meat cholesterol content of broiler. Two hundred sixteen DOCs CP707 strain were reared for four weeks in high stocking density of 15 birds $/ \mathrm{m}^{2}$. The birds were subjected to experimental drinking waters with or without water extracted beluntas leaf $(\mathrm{v} / \mathrm{v})$ and sugar which is consisted of T1 (only drinking water), T2 (drinking water + commercial antistress), $\mathrm{T} 3$ (drinking water $+10 \%$ extract of beluntas leaf ), T4 (drinking water $+20 \%$ extract of beluntas leaf), T5 (drinking water $+40 \%$ extract of beluntas leaf), T6 (drinking water $+80 \%$ extract of beluntas leaf), T7 (drinking water $+40 \%$ extract of beluntas leaf $+1.6 \%$ sugar), and T8 (drinking water $80 \%$ extract of beluntas leaf $+3.1 \%$ sugar). The results showed that water extracted beluntas leaf addition higher than $10 \%$ significantly reduced $(\mathrm{P}<0.05)$ body weight gain, final body weight, and increased $(\mathrm{P}<0.05)$ feed conversion ratio. It is concluded that the addition of water extracted beluntas leaf more than $10 \%$ into drinking water cannot give greater benefit on performances as an antistress of broiler. Sugar addition cannot help the disadvantage due to the bitter taste of higher level of water extracted beluntas leaf addition.

Key words: water extracted beluntas leaf, sugar cane, drinking water, antistress, broiler performances

\footnotetext{
* Corresponding author:

E-mail: a_sudarman@yahoo.com
} 


\section{INTRODUCTION}

Broiler chicken will experience heat stress when they are reared in hot environment or in high stocking density ( $>10 \mathrm{head} / \mathrm{m}^{2}$ ) indicated such as by increase leucocytes number, and lower their performance. To solve the problem the farmers usually providing the stress animal with commercial synthetic antistress drugs which were added into the drinking water. However, it is considered less efficient because of the price of synthetic antistress drugs are relatively expensive and less profitable for farmers. It is therefore necessary to find a natural antistress drug which is cheaper and easier to obtain, such as beluntas (Pluchea indica L.) leaf. Beluntas has commonly used by Indonesian people which has benefits in humans in particular can lower the body temperature and for the treatment of nerve. It reported that beluntas contains amino acids (leucine, isoleucine, tryptophan, threonine), alkaloids, flavonoids, essential oil, chlorogenik acid, sodium, potassium, calcium, magnesium, phosphorus, iron, vitamin A and C (Setiaji \& Sudarman, 2005).

Previous results (Setiaji \& Sudarman, 2005) showed that water extracted beluntas leaf could be added into drinking water, as cheaper and safer herb anti-stress, up to $10 \%(\mathrm{v} / \mathrm{v})$ to replace the synthetic anti-stress commonly practiced in broiler industry as indicated by the leukocyte number of beluntas addition groups (19.20$30.30 \times 10^{3} / \mathrm{mm}^{3}$ ) was similar with that of synthetic antistress addition group $\left(26.0 \times 10^{3} / \mathrm{mm}^{3}\right)$, but significantly $(\mathrm{P}<0.05)$ lower than that of control group $\left(40.10 \times 10^{3} /\right.$ $\mathrm{mm}^{3}$ ). They also reported that water extracted beluntas leaf had significantly $(\mathrm{P}<0.05)$ affected feed intake and feed conversion ratio of broiler chicken.

It is therefore important to explore further information of maximum benefit of the addition of water extract beluntas leaf as an antistress. However, addition of water extracted beluntas leaf more than $10 \%$ will cause rather bitter taste of drinking water due to the tannin content and may be refused by the chicken. It may be possible to overcome the bitter taste of drinking water due to water extracted beluntas leaf addition in greater amount by adding sugar cane as it has a sweet taste. Heat stress animal usually requires more energy. Sugar is also a readily available carbohydrate, thus a good source of energy for animal, together with substances contained in water extracted beluntas leaf, may be able to overcome heat stress better.

The objective of this experiment was to study whether the addition of water extracted beluntas leaf in level of higher than $10 \%$ of drinking water can give greater benefit on performances and meat cholesterol content of broiler. The effect of addition of sugar to reduce bitter taste due to higher tannin content of water extracted beluntas leaf in higher than $10 \%$ was also studied.

\section{MATERIALS AND METHODS}

Two hundred and sixteen DOCs of CP 707 strain were allocated into eight treatments of experimental drinking water and reared for four weeks. They were placed in 24 cages $(1 \times 1 \times 0.6 \mathrm{~m})$ each containing nine birds in equal to stocking density of $15 \mathrm{birds} / \mathrm{m}^{2}$. The density of 15 birds $/ \mathrm{m}^{2}$ was designed to make the broiler to be in stressful condition as it was described in previous studies (Dozier III et al., 2006; Sudarman et al., 2011).

During the first week, 60 watt bulb lamp was provided on each cage and switched on for $24 \mathrm{hrs}$ as a heater and for the rest of weeks they were switched on only in the night. Diet used in mesh form was bought from PT Charoen Pokphand containing metabolizable energy (ME) and crude protein for starter period (0-3 weeks) were $3,000 \mathrm{kcal} / \mathrm{kg}$ and $22 \%$, and for finisher (3-4 weeks) were $3,100 \mathrm{kcal} / \mathrm{kg}$ and $20 \%$, respectively as shown in Table 1.

The treatments were $\mathrm{T} 1$ (only drinking water), T2 (drinking water + commercial antistress), T3 (drinking water $+10 \%$ water extracted beluntas leaf), T4 (drinking water $+20 \%$ water extracted beluntas leaf), T5 (drinking water $+40 \%$ water extracted beluntas leaf), T6 (drinking water $+80 \%$ water extracted beluntas leaf), $\mathrm{T} 7$ (drinking water $+40 \%$ water extracted beluntas leaf $+1.6 \%$ sugar $)$, and T8 (drinking water $+80 \%$ water extracted beluntas leaf $+3.1 \%$ sugar). Water extracted beluntas leaf and sugar were added into drinking water based on volume/ volume $(\mathrm{v} / \mathrm{v})$ and weight/volume $(\mathrm{w} / \mathrm{v})$, respectively. Feed and drinking water were offered ad libitum.

Crude water extraction of beluntas leaf: the leaf was first washed, then chopped up using blender with addition of warm water $\left(70-80^{\circ} \mathrm{C}\right)$ in ratio of 1:2 for leaf and water, respectively. Finally, the blended of beluntas leaf was sieved and the extract was added into drinking water and was given continuously for four weeks.

At $3 \mathrm{~d}$ of age, birds were vaccinated with ND1 vaccine through eye drops, followed by gumboro and ND2 vaccines through drinking water at $10^{\text {th }}$ and $21^{\text {st }} \mathrm{d}$ of age, respectively. A commercial antistress product was added into drinking water on T2 (positive control). The commercial antistress composition was shown in Table 2.

The variables measured were daily water intake, weekly feed intake, weight gain, final body weight and feed conversion ratio was calculated at the last day of experiment. Similar to the previous study (Sudarman et al., 2011), at the end of rearing period, two birds per treatment were slaughtered for meat cholesterol content

Table 1. Nutrient content of commercial feed used in this experiment

\begin{tabular}{lrc}
\hline Nutrients & Starter & Finisher \\
\hline Water, \% & 13.0 & 13.0 \\
Crude Protein, \% & 22.0 & 20.0 \\
Fat, \% & 5.0 & 5.0 \\
Fibre, \% & 5.0 & 5.0 \\
Ash, \% & 7.0 & 7.0 \\
Calcium, \% & 0.9 & 0.9 \\
Phosphorus, \% & 0.6 & 0.6 \\
Metabolizable energy, kcal/kg & 3,000 & 3,100 \\
\hline
\end{tabular}

Source: PT. Charoen Phokphand (2005). 
Table 2. Nutrient content of commercial anti-stress

\begin{tabular}{lc}
\hline Nutrients & Amount/kg \\
\hline Vitamin A & $6.000 .000 \mathrm{IU}$ \\
Vitamin D3 & $1.200 .000 \mathrm{IU}$ \\
Vitamin E & $2.500 \mathrm{IU}$ \\
Vitamin K3 & $3 \mathrm{~g}$ \\
Vitamin B1 & $2 \mathrm{~g}$ \\
Vitamin B2 & $3 \mathrm{~g}$ \\
Vitamin B6 & $1 \mathrm{~g}$ \\
Vitamin B12 & $2 \mathrm{mg}$ \\
Vitamin C & $20 \mathrm{~g}$ \\
Nicotinic acid & $15 \mathrm{~g}$ \\
Calcium-D-pantotenic & $5 \mathrm{~g}$ \\
Electrolit such as Na, K, Ca, and Mg & $750 \mathrm{~g}$ \\
\hline
\end{tabular}

Source: PT. Medion (2005).

analysis. Meat cholesterol content was measured from right leg sample (composite of two legs of two birds) using Lieberman Burchard method (Kleiner \& Dotti, 1962) and data were analyzed using descriptive statistics. Experimental design used was completely randomized design (CRD) with eight treatments and three replicates consisting nine birds per replicate. Data (weekly feed intake and body weight gain, final body weight, feed conversion ratio (FCR), and daily water intake) were analyzed using ANOVA and any mean differences were further tested using least significant difference (LSD) (Steel \& Torrie, 1980).

\section{RESULTS AND DISCUSSION}

Effects of water extracted beluntas leaf addition into drinking water on feed intake, body weight gain, final body weight, feed conversion ratio, and water intake of broiler reared for four weeks were shown in Table 3. Beluntas is a herb containing bioactive compounds such as phenol hydroquinone, tannin, alkaloid, and steroid (Ardiansyah et al., 2003), and essential oil (sesquiterpenoids, 0.09\%) (Chong, 2011). Flavonoid (Panovskai et al., 2005) and polifenol (Huda-Faujan et al., 2007; Huda-Faujan et al., 2009) has an antioxidants activity together with vitamin $\mathrm{C}$ and carotenoid protect body tissue from damage due to oxidative stress (Scalbert \& Williamson, 2000). However, beluntas also contains high tannin $(1.88 \%)$, an anti nutrition substance (Rukmiasih et al., 2010). Diet containing high dietary tannins reduced weight gains and feed efficiencies in birds (Iji et al., 2004).

\section{Water Intake}

Water extracted beluntas leaf addition into drinking water significantly $(\mathrm{P}<0.05)$ affected water intake. The higher level of water extracted beluntas leaf in the drinking water, the lower water intake of broiler. Water intakes of broiler given water extracted beluntas leaf into drinking water up to $40 \%$ without sugar (T4) though lower, but were not significantly different from those of control groups (T0 and T1). However, water intake of those given $80 \%$ water extracted beluntas leaf (T5) was significantly $(\mathrm{P}<0.05)$ lower than that of negative control group (T0) (Table 3). This showed that broiler did not like drinking water with addition of water extracted beluntas leaf more than $40 \%$. Adding sugar cane into drinking water containing high level of water extracted beluntas leaf $(40 \%$ (T6) and 80\% (T7)) decreased further water intake and significantly $(\mathrm{P}<0.05)$ lower compared to control groups (T0 and T1).

Beluntas leaf contains tannin of $1.88 \%$ (Rukmiasih et al., 2010) causing bitter taste. The lower water intake of birds given drinking water containing $80 \%$ water extracted beluntas leaf was due to its higher tannin content than other treatments, resulted in more bitter taste which seemed broiler did not like it. It is in accordance with Kudo et al. (2010) who reported that broiler is very sensitive to the bitter taste.

Table 3. Growth performances of broiler as affected by water extracted beluntas leaf and sugar cane addition into drinking water

\begin{tabular}{cccccc}
\hline Treatments & $\begin{array}{c}\text { Water intake } \\
(\mathrm{ml} / \mathrm{bird})\end{array}$ & $\begin{array}{c}\text { Feed intake } \\
(\mathrm{g} / \mathrm{bird})\end{array}$ & $\begin{array}{c}\text { Body weight gain } \\
(\mathrm{g} / \mathrm{bird} / \mathrm{d})\end{array}$ & $\begin{array}{c}\text { Final body weight } \\
\text { (g/bird) }\end{array}$ & $\begin{array}{c}\text { FCR } \\
(\text { Feed:gain, g/g) }\end{array}$ \\
\hline T0 & $3776 \pm 107^{\mathrm{a}}$ & $1666 \pm 7^{\mathrm{a}}$ & $29.9 \pm 1.2^{\mathrm{abc}}$ & $874 \pm 35^{\mathrm{abc}}$ & $1.99 \pm 0.08^{\mathrm{a}}$ \\
T1 & $3751 \pm 189^{\mathrm{ab}}$ & $1588 \pm 35^{\mathrm{ab}}$ & $30.7 \pm 0.4^{\mathrm{ab}}$ & $899 \pm 11^{\mathrm{ab}}$ & $1.85 \pm 0.06^{\mathrm{bc}}$ \\
T2 & $3627 \pm 66^{\mathrm{abc}}$ & $1574 \pm 32^{\mathrm{b}}$ & $31.8 \pm 0.6^{\mathrm{a}}$ & $928 \pm 17^{\mathrm{a}}$ & $1.77 \pm 0.05^{\mathrm{c}}$ \\
T3 & $3582 \pm 199^{\mathrm{abc}}$ & $1579 \pm 28^{\mathrm{b}}$ & $29.0 \pm 0.8^{\mathrm{bc}}$ & $850 \pm 22^{\mathrm{bc}}$ & $1.95 \pm 0.06^{\mathrm{ab}}$ \\
T4 & $3558 \pm 149^{\mathrm{abc}}$ & $1546 \pm 26^{\mathrm{b}}$ & $28.1 \pm 1.3^{\mathrm{cd}}$ & $826 \pm 38^{\mathrm{cd}}$ & $1.96 \pm 0.09^{\mathrm{ab}}$ \\
T5 & $3532 \pm 14^{\mathrm{bc}}$ & $1540 \pm 75^{\mathrm{b}}$ & $29.1 \pm 1.4^{\mathrm{bc}}$ & $855 \pm 37^{\mathrm{bc}}$ & $1.89 \pm 0.12^{\mathrm{abc}}$ \\
T6 & $3409 \pm 68^{\mathrm{c}}$ & $1315 \pm 91^{\mathrm{c}}$ & $25.8 \pm 2.2^{\mathrm{e}}$ & $761 \pm 62^{\mathrm{e}}$ & $1.83 \pm 0.13^{\mathrm{bc}}$ \\
T7 & $3393 \pm 163^{\mathrm{c}}$ & $1280 \pm 13^{\mathrm{c}}$ & $26.1 \pm 1.0^{\mathrm{de}}$ & $770 \pm 27^{\mathrm{de}}$ & $1.75 \pm 0.05^{\mathrm{c}}$ \\
\hline
\end{tabular}

Note: Means in the same column with different superscript differ significantly $(\mathrm{P}<0.05)$.

T0 (drinking water only, as negative control), T1 (drinking water + commercial antistress, as positive control), T2 (drinking water $+10 \%$ extract of beluntas leaf), T3 (drinking water $+20 \%$ extract of beluntas leaf), T4 (drinking water $+40 \%$ extract of beluntas leaf), T5 (drinking water $+80 \%$ extract of beluntas leaf), T6 (drinking water $+40 \%$ extract of beluntas leaf $+1.6 \%$ sugar), and T7 (drinking water $80 \%$ extract of beluntas leaf + $3.1 \%$ sugar). 
Adding sugar into high level of water extracted beluntas leaf $40 \%$ (T6) and 80\% (T7) into drinking water was previously aimed to overcome the bitter taste of the drinking water, specially for T6 and T7 treatment groups. However, the results showed that the broiler did not like water containing sugar and hence the water intake of T6 and T7 were low. This is in line with Damron (2003) who reported that chickens actually avoid saccharine and sweet flavors.

Sugar is readily available carbohydrate and energy, when it is consumed by animal can cause its blood glucose to increase in short time. High blood glucose level is one of causes the animal to have satiated filling. Thus, it is possible that due to blood glucose of T6 and T7 groups increase immediately after drinking caused the animal to stop drinking. This resulted in reduction of water intake in those groups. Another possibility is that sugar added into drinking water of T6 and T7 groups had contribution to energy consumed by the animals, besides feed originated energy. Energy is the primary nutrient required by animal, when its requirement has been fulfilled they will stop to eat or drink. Energy content of sugar is $3750 \mathrm{kcal} / \mathrm{kg}$ (Leeson \& Summers, 2001), so that sugar addition into T6 and T7 provided $203 \mathrm{kcal} /$ $\mathrm{kg}$ and $410 \mathrm{kcal} / \mathrm{kg}$, respectively.

\section{Feed Intake}

Broilers given water extracted beluntas leaf into drinking water did not make any differences in feed intake (Table 3). Sugar addition into drinking water (T6) and (T7) further decreased feed intake and significantly lower than those without sugar addition eventhough they were given similar level of water extracted beluntas leaf.

As it is explained before that the bitter taste of beluntas leaf is due to its tannin content, thus the higher proportion of water extracted beluntas leaf in the drinking water the higher the tannin contained, resulted in the bitterer the drinking water taste. Bitter drinking water was consumed in little quantity. It is well known that water intake has strong correlation with feed intake, so that when water intake drop, the feed intake will decrease. In this study there is strong correlation between feed and water intake as indicated by their high correlation coefficient (r) of 0.90 . Thus lower water intake of broiler given higher level of water extracted beluntas leaf resulted in lower feed intake. This result was in accordance with the result of Damron et al. (1986) who reported a reduction in feed intake from a bitter alkaloid taste of weed seed such as crotalaria.

The decrease in feed intake in the present experiment was more pronounce when sugar was added into drinking water containing water extracted beluntas leaf. This possibly due to that water and feed intake has strong correlation, thus as the water intake decreased by adding sugar where it contributed to energy consumed by the animals and so the feed intake.

Water: feed intake ratio in this study was in average $2.38 \pm 0.15$. This value was lower than those of our previous result by giving beluntas leaf meal into the diet, i.e., $2.63 \pm 0.1$ (Sudarman et al., 2011). It is well known that limited water intake decreases feed intake. In this study, water intake was limited by bitter taste of water extracted beluntas leaf addition. The highest feed intake of T2 group (1574 g) was still lower compared to the highest feed intake in previous study (1691 g) (Sudarman et al., 2011) where the broilers had unlimited access to drinking water.

\section{Body Weight Gain and Final Body Weight}

Water extracted beluntas leaf addition into drinking water significantly $(\mathrm{P}<0.05)$ affected body weight gain and final body weight of broilers. Broilers given $10 \%$ water extracted beluntas leaf (T2) had higher body weight gain and final body weight compared to those of broilers given higher level water extracted beluntas leaf, but similar to those of control groups of T1 (Table 3). Adding sugar into drinking water containing water extracted beluntas leaf lowered body weight gain and final body weight.

Addition of water extracted beluntas leaf at the level of $10 \%$ up to $80 \%$ into drinking water eventhough did not cause feed intake significantly different, but caused body weight gain and final body weight were significantly $(\mathrm{P}<0.05)$ different. Body weight gain and final body weight are usually affected by feed intake, however in this experiment chemical content of $P$. indica leaf seemed to have effect more than feed intake on body weight gain and final body weight. Beluntas leaf contains essential oil and flavonoid. Essential oil has a positive effect on high body weight gain (Lee et al., 2004). This oil (Friedman, et al., 2002) and flavonoid (Lima et al., 2009) have an anti-bacterial activities that kill harmful bacteria. Thus the process of digestion and absorption was not disturbed and utilization of nutrients become more efficient. However, intake of flavonoid in excess is not beneficial, since it caused to reduce growth (Hughes et al., 2005) and disrupted thyroid function (Giuliani et al., 2008). This was shown by giving water extracted beluntas leaf more than 10\% (T3-T7) resulted in lower weight gain and final body weight. This confirmed previous result (Setiaji \& Sudarman, 2005) that the optimum level of water extracted beluntas leaf addition into drinking water was at the level of $10 \%$.

Adding sugar did not help the negative effect of water extracted beluntas leaf in higher level. Moreover, it deteriorated broiler weight gain and final body weight as shown by those at T6 and T7 (Table 3). Broilers given drinking water containing higher level of water extracted beluntas leaf added by sugar (T6 and T7) had lower $(\mathrm{P}<0.05)$ body weight gain and final body weight compared to those of other groups. This surely due to the direct effect of decreasing in water and feed intake of those two groups.

\section{Feed Conversion}

Feed conversion ratio (FCR) measured from broilers reared for four weeks in this study is presented in Table 3. Water extracted beluntas leaf addition into diet significantly $(\mathrm{P}<0.05)$ affected feed conversion ratio. Broiler in T2 group, given drinking water containing 
water extracted beluntas leaf at the level of $10 \%$ resulted in the lowest $(\mathrm{P}<0.05) \mathrm{FCR}$ among other groups of without sugar addition. Increasing level of water extracted beluntas leaf addition into drinking water exacerbated FCR of broilers (T3-T5). This showed that addition of water extracted beluntas leaf in different levels caused the difference in feed utilization efficiency. Adding 10\% water extracted beluntas leaf seemed to improve nutrient utilization efficiency compared to the others. Previous result (Setiaji \& Sudarman, 2005) showed that addition of $10 \%$ of water extracted beluntas leaf into drinking water gave better FCR value compared to those given $5 \%$ or $0 \%$ (control) groups. This supported the present result that the lowest FCR value of T2 group given 10\% of water extracted beluntas leaf may indicated that the diet they fed could be optimally digested, absorbed, and utilized better than other diets. This might be due to the positive role of active substances contained in beluntas leaf, such as essential oil and flavonoid. According to Malayoğlu et al. (2010), essential oil has an effect to increase protein digestibility. Flavonoid has an effect of antimicrobial activity. However, in excess intake of such active substances reduced feed utilization efficiency so that feed conversion value increased as shown in the broilers fed diet T3, T4, and T5.

FCR of broiler given high level of water extracted beluntas leaf in the drinking water (T6 and T7) and sugar tended to be better than those of broiler given only water extracted beluntas leaf in the drinking water (T4 and T5). The lower FCR value of those given high level of water extracted beluntas leaf and glucose could be explained due to positive relationship between FCR and water intake, i.e., the lower water intake of broiler, the lower their FCR value (Table 3). Low water intake may cause the rate of digesta passage in gastrointestinal tract to slow resulted in increase absorption of nutrients, and improve feed efficiency utilization.

\section{Cholesterol Content of Meat}

Effect of water extracted beluntas leaf addition into diet on cholesterol content of broiler meat is presented in Figure 1. Broilers given water extracted beluntas leaf in the drinking water produced meat with lower cholesterol content than positive control group (T1), except those given drinking water with $20 \%$ water extracted beluntas leaf (T3). The lowest cholesterol content of meat was obtained with the addition of water extracted beluntas leaf at level of $80 \%$. This result confirmed the previous result of Sudarman et al. (2011) that the higher the addition level of $P$. indica leaf, the lower cholesterol content in meat. Adding sugar into drinking water containing water extracted beluntas leaf of $40 \%$ (T6) and $80 \%$ (T7) further decreased cholesterol content of broiler meat.

Interesting result was shown by the negative control group (T0) that had lower meat cholesterol content than those of the groups with the addition of commercial antistress or of water extracted beluntas leaf, except for that of the addition of $80 \%$ water extracted beluntas leaf (T5). T0 group was assumed to experience heat stress more than the others. Neither stress animal produced less cholesterol than unstress animal nor sugar addition into drinking water could reduced cholesterol content of meat were still unclear.

As it is described above, beluntas leaf contained active substances, such as alkaloid, flavonoid, essential oil, and clorogeic acid. Flavonoid (theaflavins) has an effect to reduce cholesterol in blood serum through inhibiting micelle formation in small intestine so that decrease intestinal cholesterol absorption (Vermeer et al., 2008). Essential oil contained in beluntas leaf has an effect to increase bile acids secretion (Lin et al., 2008) where cholesterol in the body can be eliminated through its conversion by liver into bile acids which is bound to glycine and taurine to form bile salts and secreted to duodenum which then degraded by microbes in the gut

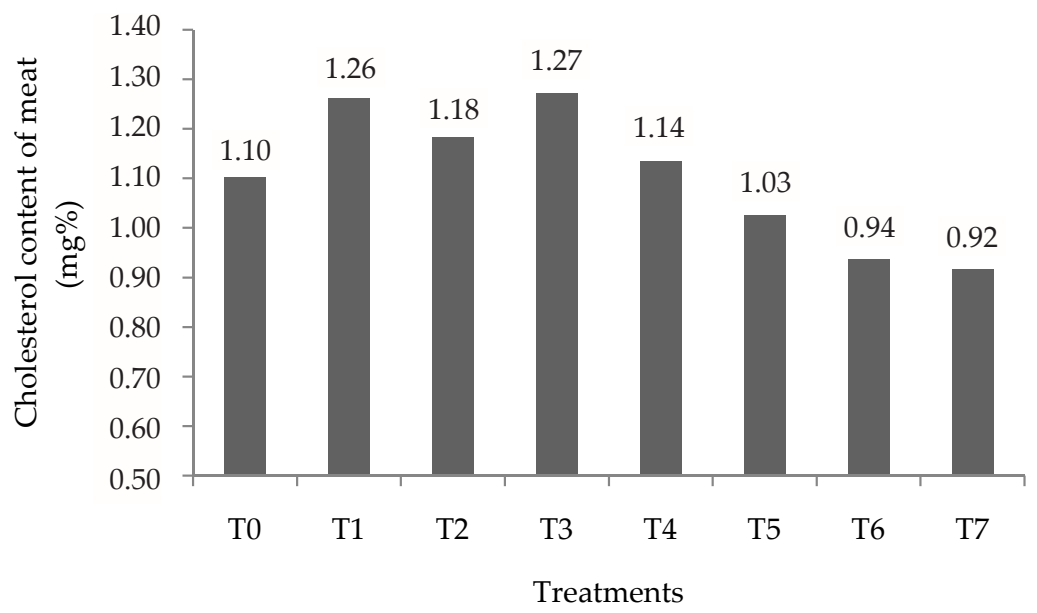

Figure 1. Cholesterol content of broiler meat as affected by addition of water extracted beluntas leaf into drinking water. T0 (drinking water only, as negative control), T1 (drinking water + commercial antistress, as positive control), T2 (drinking water $+10 \%$ extract of beluntas leaf), T3 (drinking water $+20 \%$ extract of beluntas leaf), T4 (drinking water $+40 \%$ extract of beluntas leaf), T5 (drinking water $+80 \%$ extract of beluntas leaf), T6 (drinking water $+40 \%$ extract of beluntas leaf $+1.6 \%$ sugar), and T7 (drinking water $80 \%$ extract of beluntas leaf $+3.1 \%$ sugar). 
and excreted together with feces, so that body cholesterol content decrease and may caused the reduction of cholesterol in broiler meat.

\section{CONCLUSION}

Water extracted beluntas leaf addition more than $10 \%$ into drinking water as an antistress cannot give greater benefit as indicated by lower performance of broiler. Sugar addition cannot solve the negative effect of bitter taste of drinking water containing extracted beluntas leaf at high level.

\section{REFERENCES}

Ardiansyah, L. Nuraida, \& N. Andarwulan. 2003. Antimicrobial activity of beluntas (Plucea indica L.) leaves extract and stability of the activity at different salt concentrations and pHs. JTIP 14: 90-106

Chong, W. K. 2011. Isolation and identification of some rare compounds from essential oils. http://chem.usm.my/ bulletin\%20kimia/kimia_usm2.pdf [12 November 2011]

Damron, B. L., L. S. Kelly \& S. F. Sundlof. 1986. Relationship of reduced feed intake and crotalaria contamination of hen feeds. Poultry Sci. 65, Supplement 1:30.

Damron, B. L. 2003. Feed Flavoring for Poultry. Institute of Food and Agricultural Sciences, University of Florida.

Dozier III, W. A., J. P. Thaxton, J. L. Purswell, H. A. Olanrewaju, S. L. Branton, \& W. B. Roush. 2006. Stocking density effects on male broilers grown to 1.8 kilograms of body weight. Poult. Sci. 85:344-351

Friedman, M., P. R. Henika, \& R. E. Mandrell. 2002. Bactericidal activities of plant essential oils and some of their isolated constituents against Campylobacter jejuni, Escherichia coli, Listeria monocytogenes, and Salmonella enteric. J. Food Protec. 65: 1545-1560.

Giuliani, C., Y. Noguchi, N. Harii, G. Napolitano, D. Tatone, I. Bucci, M. Piantelli, F. Monaco, \& L. D. Kohn. 2008. The flavonoid quercetin regulates growth and gene expression in rat FRTL-5 thyroid cells. Endocrinology 149: 84-92. http://dx.doi.org/10.1210/en.2007-0618

Huda-Faujan, N., A. Noriham, A. S. Norrakiah, \& A. S. Babji. 2007. Antioxidative activities of water extracts of Malaysian herbs. ASEAN Food J. 14:61-68.

Huda-Faujan, N., A. Noriham, A. S. Norrakiah, \& A. S. Babji. 2009. Antioxidative activities of plants methanolic extracts containing phenolic compounds. Afr. J. Biotechnol. 8: 484489.

Hughes, R. J., J. D. Brooker, \& C. Smyl. 2005. Growth rate of broiler chickens given condensed tannins extracted from grape seed. Aust. Poult. Sci. Symp. 17: 65-68.

Iji, P. A., K. Khumalo, S. Slippers, \& R. M. Gous. 2004. Intestinal function and body growth of broiler chickens on maize-based diets supplemented with mimosa tannins and microbial enzyme. J. Sci. Food Agric. 84: 1451-1458. http://dx.doi.org/10.1002/jsfa.1816
Kleiner, I. S. \& L. B. Dotti. 1962. Laboratory Instruction in Biochemistry. $6^{\text {th }}$ ed. The C.V. Mosby Company, New York.

Kudo, K., J. Shiraishi, S. Nishimura, T. Bungo, \& S. Tabata. 2010. The number of taste buds is related to bitter taste sensitivity in layer and broiler chickens. J. Anim. Sci. 81: 240244. http://dx.doi.org/10.1111/j.1740-0929.2009.00729.x

Lee, K.-W., H. Everts, H.J. Kappert, J. Van Der Kuilen, A.G. Lemmens, M. Frehner \& A.C. Beynen. 2004. Growth Performance, Intestinal Viscosity, Fat Digestibility and Plasma Cholesterol in Broiler Chickens Fed a Rye-containing Diet Without or with Essential Oil Components. Int. J. Poult. Sci. 3: 613-618. http://dx.doi.org/10.3923/ijps.2004.613.618

Leeson, S. \& J. D. Summers. 2001. Scott's Nutrition of The Chicken. $4^{\text {th }}$ ed. Nottingham University Press, England.

Lima, B., M. B. Agŭero, J. Zygaldo, A. Tapiai, C. Solis, A. R. De Arias, G. Yaluff, S. Zacchino, G. E. Feresin, \& G. S. Hirschman. 2009. Antimicrobial activity of extracts, essential oil and metabolites obtained from Tagetes mendocina. J. Chil. Chem. Soc. 54: 68-72. http://dx.doi.org/10.4067/ S0717-97072009000100016

Lin, L. Y., C. C. Peng, Y. J. Liang, W. T. Yeh, H. E. Wang, T. H. Yu, \& R. Y. Peng. 2008. Alpinia zerumbet potentially elevates high-density lipoprotein cholesterol level in hamsters. J. Agric. Food Chem. 56: 4435-4443. http://dx.doi. org/10.1021/jf800195d

Malayoğlu, H. B., Ş. Baysal, Z. Misirlioğlu, M. Polat, H. Yilmaz, \& N. Turan. 2010. Effects of oregano essential oil with or without feed enzymes on growth performance, digestive enzyme, nutrient digestibility, lipid metabolism and immune response of broilers fed on wheat-soybean meal diets. Br. Poult. Sci. 51:67-80.

Panovskai, T. K., S. Kulevanova, \& M. Stefova. 2005. In vitro antioxidant activity of some Teucrium species Lamiaceae. Acta Pharm. 55: 207-214.

Rukmiasih, P. S. Hardjosworo, W. G. Piliang, J. Hermanianto, \& A. Apriyantono. 2010. Performance, chemical quality, and off -odor of duck's meat (Anas plathyrynchos) fed beluntas (Pluchea indica L. Less) containing ration. Med. Pet. 34: 68-75. http://dx.doi.org/10.5398/medpet.2010.33.2.68

Scalbert, A. \& G. Williamson. 2000. Dietary intake and bioavailability of polyphenols. J. Nutr. 130: 2073S-2085S.

Setiaji, D. \& A. Sudarman. 2005. Ekstrak daun beluntas (Pluchea indica Less.) sebagai obat antistres pada ayam broiler. Med. Pet. 28: 46-51.

Steel, R. G. D. \& J. H. Torrie. 1980. Principles and Procedures of Statistics: A Biometric Approach. McGraw-Hill Book Co., New York.

Sudarman, A., Sumiati, \& S. H. Solikhah. 2011. Performance and meat cholesterol content of broiler chickens fed Pluchea indica L. leaf meal reared under stress condition. Med. Pet. 34: 63-67. http://dx.doi.org/10.5398/medpet.2011.34.1.64

Vermeer, M. A., T. P. J. Mulder, \& H. O. F. Molhuizen. 2008. Theaflavins from black tea, especially theaflavin-3-gallate, reduce the incorporation of cholesterol into mixed micelles. J. Agric. Food Chem. 56: 12031-12036. http://dx.doi. org/10.1021/jf8022035 